\title{
DETERMINANTS OF CORPORATE SOCIAL RESPONSIBILITY DISCLOSURE IN POLISH ORGANISATIONS
}

\author{
Jolanta Maj*, Liliana Hawrysz*, Piotr Bębenek ${ }^{* * *}$
}

\begin{abstract}
Background. Studies suggest, that organisations tend to a selective disclosure of non-financial information, which may depend on the organisations characteristics, general and internal contextual factors. Furthermore it is believed that CSR disclosure is country-variant.

Research aims. Therefore the main goal of this paper is to verify, whether selected variables: the size of the company, the issue of operating on foreign markets and financial performance influence the detail of disclosed non-financial information.

Methodology. For this purpose CATI research with 102 companies listed on the Warsaw Stock Exchange has been conducted. The obtained results have been analysed using V Cramer contingency measure.

Key findings. The conducted research and analysis have shown that in most cases a statistically significant correlation between the analysed variables could not been determined. A statistically important correlation has been determined between i.e. the size of the company and the disclosure of social and employee related information towards internal stakeholders, between operating on foreign markets and the disclosure of social and employee related information towards external stakeholders and between financial performance and disclosure towards external stakeholders in regards to three dimensions.
\end{abstract}

Keywords: corporate social responsibility, reporting of non-financial data, organisation's social responsibility, sustainability reporting, non-financial information disclosure.

* Opole University of Technology. E-mail: j.maj@po.opole.pl

** Opole University of Technology. E-mail: 1.hawrysz@po.opole.pl

*** Opole University of Technology. E-mail: p.bebenek@po.opole.pl 


\section{INTRODUCTION}

Corporate social responsibility (CSR) has a long history, dating back to the 50s of the XX century and undergoing since than many changes (Moura-Leite \& Padgett, 2011). During this time CSR has been a subject of interest for decision makers at the national and international level, which resulted in the adoption of several declarations, documents and international laws (Hawrysz, 2017). One of the most active international actors has been the European Union, which recognized CSR as an important issues of economic policy and started initiatives across Europe to legally regulate CSR issues (Skrzypek, 2015). The last manifestation of the legal regulation of issues related to CSR has been the Directive 2014/95/EU, which obligates large public interest organisations meeting additional requirements regarding the number of employees, balance sheet total, and net turnover to disclose non-financial and diversity information. The Directive 2014/95/EU defines organisations that are obliged to disclose non-financial and diversity information as large public interest organisations meeting additional requirements regarding the number of employees, balance sheet total and net turnover. This regulation concerns approximately 6,000 large entities functioning within the EU area, including 483 Polish entities based, on the estimations of the Minister of Finances. According to Act of 7 May 2009 (uniform text; Polish Journal of Laws; Dz.U. of 2015, item 1011), public interest companies include: issuers of securities approved for trading in the regulated market of an EU state, with registered seat within the territory of that state (excluding local government units), domestic banks, branches of credit institutions and branches of foreign banks, savings and credit unions, insurance companies and main branches of insurance companies as well as reinsurance companies, open pension funds and common pension funds, open investment funds, open special investment funds and closed public investment funds, and entities conducting brokerage activities. Therefore, public interest entities embrace issuers of securities and entities from the financial sector. It would be difficult to find an entity that is not affected by the above entities. Organisations meeting those requirements are obliged to disclose the information as of 1 January 2017 (European Commission, 2014). However, as previous research shows (Hawrysz, 2016a, 2016b; Maj, 2017) Polish organizations are not inclined to disclose non-financial information. 
According to institutional and neo-institutional theories in business studies all organisations operate within a context consisting of a nexus of institutions, exerting influence on them and therefore more or less direct affecting their behaviour and functioning (Campbell, 2007). This nexus of institutions can create pressure on organisations to gain and ensure legitimization of their action. Due to the variety of institutions, especially in the neo-institutional meaning, the pressure can be coercive (the law), normative (moral compliance) and mimetic (widely accepted solutions in an industry) (Martinez-Ferrero \& Garcia-Sanchez, 2017). Therefore organisations may adopt solutions due to internal or external pressure of different nature. However the lack of formal legal norms for promotion of CSR leads to limited actions undertaken by organisations, not always meeting the requirements of the stakeholders (Garcia-Sanchez et al., 2016). Nevertheless, also where reporting requirements exists, they are unlikely to meet the requirements of the stakeholders (Williamson \& Lynch-Wood, 2008). Morover studies suggest, that organisations tend to a selective disclosure of non-financial information (Borys, 2015; Borys \& Czaja, 2009; Kleinfeld \& Martens, 2014; Kozlowski et al., 2015).

In view of the above the main goal of this paper is to identify factors influencing the disclosure of non-financial information by organisations. For this purpose from September to November 2016 a CATI research among Polish organisations listed on the Warsaw Stock Exchage has been conducted. To choice of those organisation has been dictated by the adoption of the mentioned Directive 2014/95/ EU of the European Parliament and the Council of 22 October 2014 amending Directive 2013/34 / EU as regards disclosure of non-financial and diversity information. Considering the fact that according to the provisions of the Directive obliges large public interest organisations are obliged to disclose non-financial and diversity information from January 2017, we wanted to look at these organisations before the changes. The results obraind during the research were subjected to statistical analysis.

The paper has been organized in the following way: the next section presents the state of art, which elaborates the importance and reasons for undertaking the research problem of this paper. Furthermore this section presents the hypothesis of the conducted research. The following sections gives an overview over the research methology and design including more detailed information about the research 
sample. The third section includes the research results followed by the discussion section which includes the limitations of the study as well as possible pratcial implications.

\section{DETERMINANTS OF CORPORATE SOCIAL RESPONSIBILITY REPORTING}

The issue of corporate social responsibility reporting is constantly gaining on interest from researcher (Hawrysz \& Maj, 2017; Habek, 2017; Krasodomska, 2015). As already indicated, studies suggest, that organisations tend to a selective disclosure of non-financial information. The analysis of the state of art shows that the scope of the disclosure of non-financial information may depend on various factors, which have been subject to analysis. According to Ali et al. (2017) the most often analysed determinants of CSR disclosure may be grouped into three categories: company characteristics, general contextual factors and internal contextual factor.

In the first category, company characteristics, the most often analysed determinants include for once the size of the organization; which according to Dienes et al. (2016) and Bouten et al. (2011) is one of the important drivers for sustainability reporting. This conclusion is supported also by other research (Ortas et al., 2015). Firm size is believed to have a positive influence on the scope of sustainability reporting also due to the fact, that firm size may be a proxy for political visibility and social pressure (Bewley \& Li, 2000). Another determinant of sustainability disclosure is the companies' leverage. However research regarding the influence of the companies' leverage on environmental disclosure has not reached a consensus (Fifka, 2013). Ortas et at. (2015) suggest that the greater the firms leverage the greater the scope of environmental disclosure, whereas Brammer and Pavelin (2008) found a negative relationship between those two variables. Another factor believed to positively influence the disclosure of non-financial information is the organisations performance (Khanna et al., 2004). However also in this case the literature is not consistent, as some studies have shown no significant relationship between the organizations profitability and sustainability disclosure (Clarkson et al., 2008; Ortas et al., 2015). Also operating of the organization on foreign markets is believed to positively influence CSR disclosure (Freedman \& 
Jaggi, 2011; Reverte, 2009). Other characteristics, which are believed to positively influence the corporate social responsibility disclosure are i.e. media visibility (Dienes et al., 2016) ownership structure (Dienes et al., 2016), research and development expenditures (Ortas et al., 2015) industry (Ali et al., 2017; Bouten et al., 2011; Brammer \& Pavelin, 2008; Cormier et al., 2005), age of assets (Cormier et al., 2005).

Within the general contextual factors research has shown variation between CSR practices and especially CSR disclosure (Jackson \& Apostolakou, 2010; Matten \& Moon, 2008). Differences in the effects of the national institutional context has been found between the United States and Europe (Matten \& Moon, 2008) but also between European countries (Knudsen et al., 2015). Furthermore studies have shown, that CSR disclosure may be a result of public pressure (Cormier et al., 2005) and specific concerns of specific stakeholders (Ali et al., 2017).

According to Ali et al. (2017) relatively little attention has been paid towards internal contextual factors. The so far undertaken studies have concentrated on corporate executives attitudes towards CSR disclosure (Adams, 2002). Studies have shown, that organizations disclose CSR information to gain competitive advantage (Nikolaeva \& Bicho, 2011), to present a socially responsible image (O'Donovan, 2002) or the enhance corporate reputation (Adams, 2002). Sridhar (2012), developed a model of five stages of reporting in regards to non-financial information. He distinguished following phases: stand back and wait approach, transparent and accountable, alignment of stakeholder expectations and corporate strategy, build system based on stakeholder expectations and a fully integrated approach. Through the perspective of the triple bottom line, Sridhar defines the first stage as a stage where non-financial reporting is practically non-existent and organisations concentrate on financial reporting, although they are subject to external pressure. During the second stage organisations start a dialogue with stakeholders and the idea of non-financial reporting is emerging however the organisations at this stage still are rather reactive. During the third stage organisations prepare non-financial reports and disclose economic, social and environmental information they do not however integrate it with stakeholder needs. Non-financial reporting is being functionalised. The integration of stakeholder needs and expectations into not only non-financial reporting but rather into the organisations whole system characterises the fourth stage. The final stage of the model requires a fully integrated approach, which 
may take a form of a fully integrated report including financial as well as non-financial, information. Although this Sridhar does not discus directly determinants of corporate social responsibility reporting, he shows how important internal contextual factor may be for the detail of non-financial reporting.

In view of the above presented determinants of corporate social responsibility reporting it has been decided to verify, whether chosen described dependencies are also applicable in Polish organisations. According to Gray et al. (1995) the CSR disclosure is country-variant and as shown external contextual factors may influence CSR disclosure. Furthermore most of the mentioned analyses concentrated on environmental disclosure, leaving behind other CSR dimensions like human resources, community involvement or products and consumer disclosure (Ali et al., 2017), therefore in the authors opinions it is necessary and justified to verify some of those dependencies in the Polish context. For the purpose of this paper following factors have been chosen: company size, the issue of operating on foreign market and the organisations financial performance.

In accordance with the presented state of art considering a positive relation between the size of the organization and the disclosure of CSR information we adopted the fist hypothesis:

H1: The size of the organisation influences the detail of disclosed non-financial information

In relation to the issue of operating on foreign markets we adopted the second hypothesis:

H2: The fact of operating on foreign markets by organisations will influences the detail of disclosed non-financial information

Finally in relation to the third variable, the financial performance, we adopted the thirds hypothesis:

H3: The financial performance of the organisation will influences the detail of disclosed non-financial information

\section{RESEARCH METHODOLOGY}

Our study sample included 102 companies listed on the Warsaw stock exchange. The full population included 493 organisations that were invited to take part in CATI (computer assisted telephone interview) studies. We have decided to use this method for reaching respondents 
due to the characteristic of the sample: mostly large organisations characterized by large geographic dispersion. Using CATI allows reaching a broader sample within a shorter period of time than when using traditional research methods. Also in contrast to i.e. CAWI, the response rate is higher. Using CATI research gives confidence that the respondent filling out the questionnaire is fact the person at which the questionnaire was aimed. CATI allows also control on different stages of the interview thus minimalizing mistakes while filling out the questionnaire. CATI allows verifying the entered data. It is also reduces costs and time necessary for conducting research using more traditional approaches.

The main reasons for organisations declining the participation in the study was the fact that the organisation do not have a corporate social responsibility strategy implemented and therefore do not disclose any non-financial data. Some of the Respondents stated, that for the participation in the study they would need to obtain permission from the Board.

We developed the questionnaire based on the analysis of the existing literature, however the questions included in the research tool were results operationalisation conducted by us for the purpose of this research. The variables presented in this paper, namely: environmental matters, social and employee-related matters, respect for human rights, anti-corruption and bribery matters and employee diversity were chosen due to the fact, that the mentioned Directive 2014/95/EU of the European Parliament and the Council of 22 October 2014 amending Directive 2013/34/EU as regards disclosure of non-financial and diversity information obligates organizations to disclose this particular information (European Commission, 2014). The research itself handled several questions regarding disclosure of non-financial and diversity information. The first question in the questionnaire divided the organisations into those mapping and not mapping stakeholders. In the following questions organisations declaring mapping stakeholders have been asked (where applicable) to refine the answers depending on the stakeholder group (internal and external) concerned. Hence the questionnaire for organisations mapping stakeholders consisted of 20 questions and the questionnaire for organisations not mapping stakeholder consisted of 12 questions. Hence this paper presents only a chosen part of the research. The questionnaire has been pre-test during a pilot study conducted in July 
2016. As a result of the pilot study we applied minor corrections to the questionnaire. The main study was conducted in the period from September to November 2016. The time of the study results from the Directive of the European Parliament and Council 2014/95/EU, which obliges large public interest organisations to disclose non-financial data starting from January 2017. The structure of the sample due to (not)mapping stakeholders and disclosing non-financial information has been presented in Table 1 .

Table 1. Structure of the sample due to (not)mapping stakeholders and disclosing non-financial information

\begin{tabular}{|l|c|c|c|}
\hline & $\begin{array}{c}\text { Organisations mapping } \\
\text { stakeholders }\end{array}$ & $\begin{array}{c}\text { Organisations not map- } \\
\text { ping stakeholders }\end{array}$ & Total \\
\hline $\begin{array}{l}\text { Organisations disclosing } \\
\text { non-financial information }\end{array}$ & 28 & 48 & 76 \\
\hline $\begin{array}{l}\text { Organisations not disclosing } \\
\text { non-financial information }\end{array}$ & 1 & 25 & 26 \\
\hline Total & 29 & 73 & 102 \\
\hline
\end{tabular}

Source: own research.

The characteristic of the sample due to the number of employees has been presented in Table 2 .

Table 2. The characteristic of the sample due to the number of employees and the (non)identification of stakeholder (percentage)

\begin{tabular}{|l|c|c|c|}
\hline \multicolumn{1}{|c|}{ Number of employees } & All organizations & $\begin{array}{c}\text { Organizations } \\
\text { identifying stake- } \\
\text { holders }\end{array}$ & $\begin{array}{c}\text { Organizations } \\
\text { not identifying } \\
\text { stakeholders }\end{array}$ \\
\hline Up to 9 employees & 0.99 & 0.00 & 1.39 \\
\hline From 9 to 49 employees & 8.91 & 0.00 & 12.50 \\
\hline From 50 to 249 employees & 38.61 & 13.79 & 48.61 \\
\hline From 250 to 499 employees & 16.83 & 17.24 & 16.67 \\
\hline Over 500 employees & 34.65 & 68.97 & 20.83 \\
\hline
\end{tabular}

Source: own research.

Over $2 / 3$ of all organisations identifying stakeholders are organisations employing over 500 people and are therefore subject to the Directive 2014 / 95 / EU of the European Parliament and the Council of 22 October 2014 amending Directive 2013/34/EU as regards disclosure of non-financial and diversity information, while only $20.83 \%$ of the 
organisations of this size are organisations that do not identify their stakeholders. The organisations that participated in the research represented many different sectors. In terms of this feature, the group was very diverse. The largest group included organisations from the electro-mechanical industry (12\%), food industry (10\%), other services (9\%), wholesale trade (8\%), IT sector (7\%), building materials industry (5\%), banks, retail trade, metal industry, other finances (4\%), developers, energy sector, wood industry, pharmaceuticals, plastics industry (3\%), and others. All organisations from the other services and bank sectors that took a part in the research did identify stakeholders, in contrast to the food industry, retail trade, wood industry, pharmaceuticals, and plastics industry, none of which identified their stakeholders.

Due to the fact, that the questionnaire has been build using the Likert scale for most of the questions the quantitative nature of the presented answer choices imposed the choice of tools for the analysis of quantitative variables. Therefore we chose the V Cramer contingency measure supplemented with R Spearman.

\section{RESEARCH RESULTS}

Due to the fact, that differences may exist between the willingness to disclose non-financial information towards internal and external stakeholders (Hawrysz \& Maj, 2017) the organisations have been divided between those identifying stakeholders ( $28 \%$ of the sample) and non-identifying stakeholders ( $72 \%$ of the sample). Thus the presented results have been divided into three groups: regarding disclosure towards internal and external stakeholders and stakeholders in general (for organisations not identifying stakeholders). In the presented cases the Respondents have been asked to assess the level of disclosed corporate social responsibility information in five areas indicated in the Directive 2014/95/EU: environmental matters, social and employee - related matters, respect for human rights, anti-corruption and bribery matters, employee diversity. The Respondents were asked to assess the detail of the disclosed information on a scale from 1 to 5 , where 1 meant that the organisation did not disclose any information at all and 5 meant that the organisation disclosed very detailed information.

The first analysed hypothesis (H1) was related to the influence of company size on the detail level of the disclosed non-financial 
information. The size of the company meant in this case the number of employees. The research results have been presented in Table 3 .

The obtained results are not important statistically. However it is important to notice that the values reached the coefficients Cramer's $\mathrm{V}$ give evidence of a moderate correlation between the organisations size and the detail of the disclosed non-financial information. Therefore it is not possible to determine a statistically relevant dependency between those two variables. The only case where the results are statistically important is the relation between the size of the company and the disclosure of social and employee related information towards internal stakeholders. The results may be treated as moderate (with a tendency towards high).

The second analysed hypothesis (H2) was related to the influence of the issue of operating on foreign markets on the detail of the disclosed non-financial information. The results have been presented in Table 4 .

The obtained results are not important statistically. However it is important to notice that the values reached by the coefficients Cramer's $\mathrm{V}$ give evidence of a moderate correlation between the organizations size and the detail of the disclosed non-financial information. Therefore it is not possible to determine a statistically relevant dependency between those two variables as well. The only case where the results are statistically important is the relation between operating on foreign markets and the disclosure of social and employee related information towards external stakeholders. The results may be treated as moderate correlation (with a tendency towards high).

The third analysed hypothesis (H3) was related to the influence of organisations financial performance on the detail of the disclosed non-financial information. The results have been presented in Table 5.

Although the achieved V Cramer contingency suggest a high dependency between the variables, especially in regards to eternal and internal stakeholders, the obtained results are not important statistically. Furthermore the p-value is very high; therefore we have decided to try to verify the hypothesis using a different measure, the $\mathrm{R}$ Spearman correlation. The results have been presented in Table 6 .

Also in this case most of the results obtained were not important statistically, however with a lower p-value. The values reached by the $\mathrm{R}$ Spearman show a very low correlation in relation to internal stakeholders and stakeholders in general. In the case of external stakeholders in regards to three dimensions of non-financial information: 

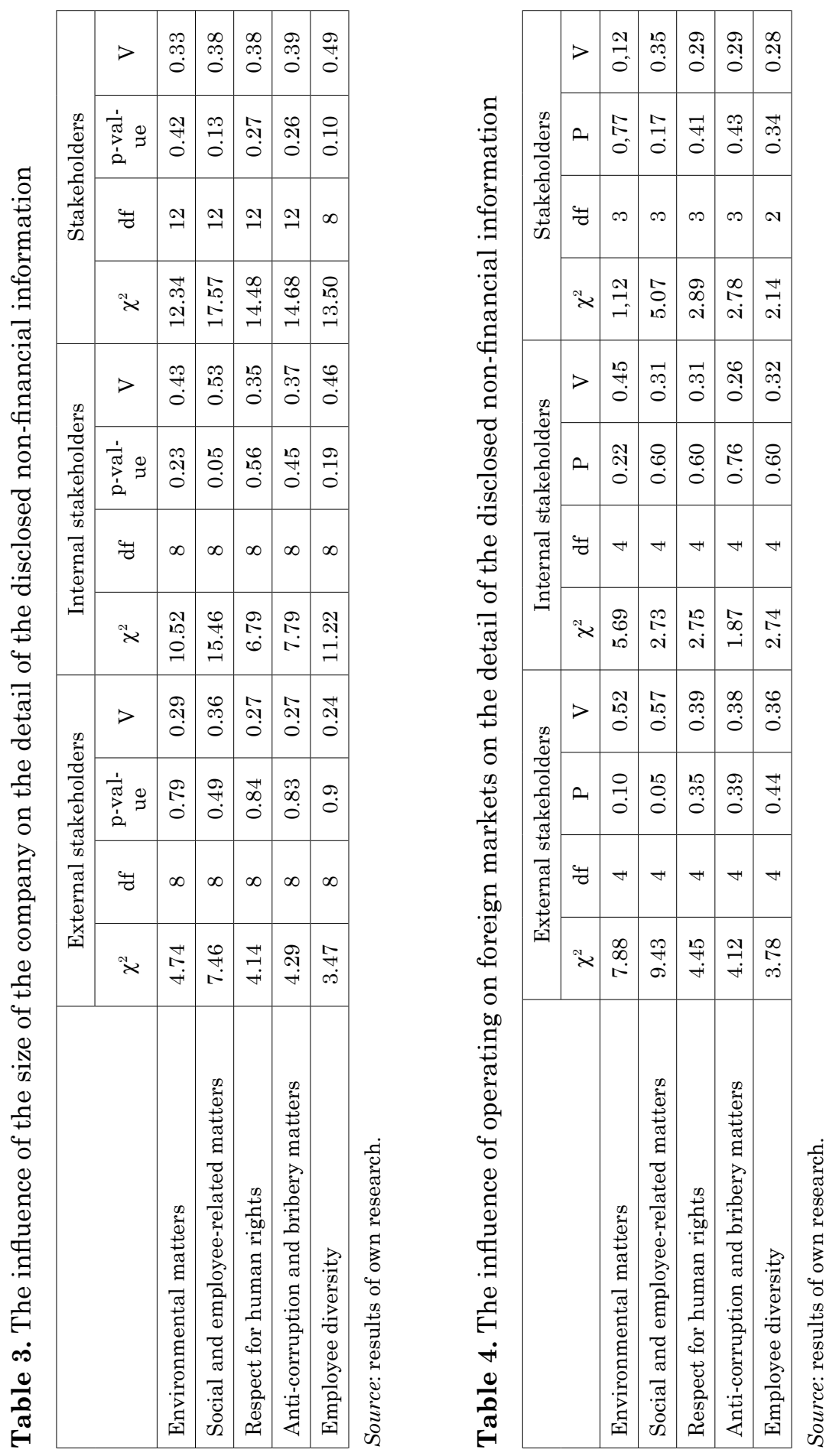

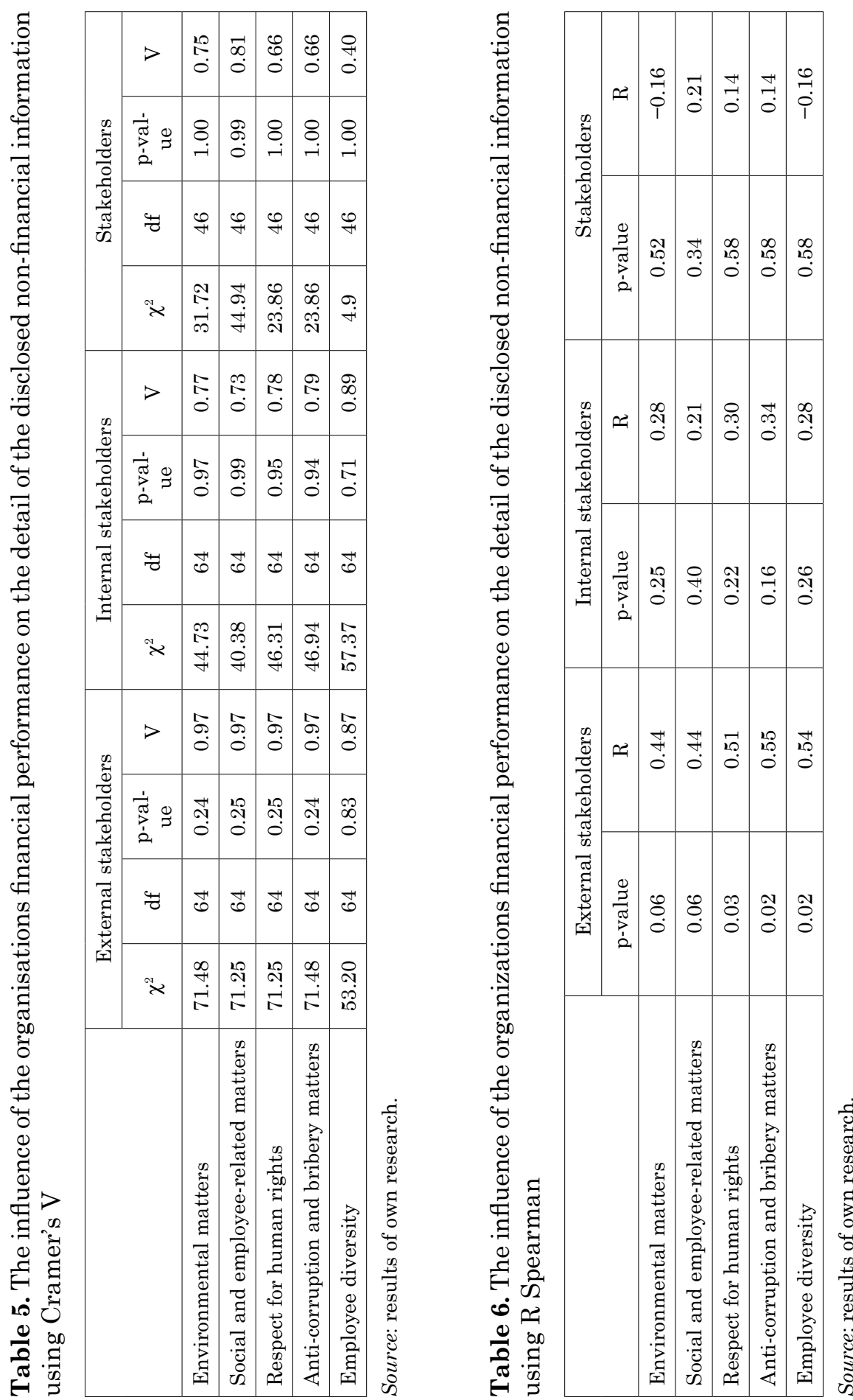
respect for human rights, anti-corruption and bribery matters as well as employee diversity the results obtained are statistically relevant and show a moderate correlation. Therefore it is not possible to determine a statistically relevant dependency between those two variables with the mentioned exception showing however a moderate correlation.

\section{DISCUSION AND CONCLUSION}

The main purpose of this paper was to verify whether selected variables: the size of the company, the issue of operating on foreign markets and financial performance influence the detail of disclosed non-financial information. The analysis has shown, that only in a few cases a statistically relevant dependency between analysed variables exists i.e. between the size of the company and the disclosure of social and employee related information towards internal stakeholders, between the fact of operating on foreign markets and the disclosure of social and employee related information towards external stakeholders and between the financial performance of the organisation and respect for human rights, anti-corruption and bribery matters as well as employee diversity. However in all cases the diagnosed dependency may only be perceived as moderate. Due to the diagnosed moderate level correlation, the issue requires however further analysis and deepening.

As already indicated the fact that the hypotheses have not been verified may result from the fact that CSR disclosure is country-variant (Ali et al., 2017; Gray et al., 1995). According to Ali et al. (2017) external contextual factors influence CSR disclosure, which may be the case also in the presented analysis. The same corporate behaviours may be acceptable in one place but not in another, which may result in differences in types of CSR disclosure. Furthermore the literature also contains examples of studies critical to the influence on i.e. size (Gallego-Alvarez et al., 2011) and financial performance (Ortas et al., 2015) on the disclosure of non-financial information.

The paper is not free of limitations. Due to the fact the only companies listed on the Warsaw Stock Exchange have been taken into consideration the results cannot be treated as representative for all Polish organisations. Furthermore the fact, that the questionnaire has been build using the Likert scale for most of the questions the quantitative nature of the presented answer choices imposed the choice 
of tools for the analysis of quantitative variables. This ruled out the possibility of using more advanced statistically measures.

The undertaken research will be continued in the following years in order to determine, if the implementation and transposition of the Directive 2014/95/EU has caused any changes in the level of disclosure of non-financial. It would also be of importance to conduct a comparative analysis with other East European Countries and with organisations disclosing non-financial information but not being the subject of the Directive 2014/95/EU. There are several possible future directions of the research. First of all the research could be enriched by including additional variables. It would be of benefit to undertake an attempt to verify the influence of variables that have already been tested however in a different national institutional context. Most of the conducted analyses have been undertaken in a West European, U.S. and Australian context. The state of art lack therefore on analyses undertaken i.e. in East European Countries. The above-presented results indicate that this may be of importance when discussing determinants of sustainability reporting. Hence it would be necessary to verify the influence of additional organisational characteristics on the disclosure of non-financial information like i.e. the media visibility, ownership structure, research and development expenditures industry, age of assets etc. Secondly it would be beneficial to determine whether other variables, which have not yet been tested influence the disclosure of corporate social responsibility information by organisations. Especially in the group of the internal contextual factors, which as already also emphasised have so far gained relatively little attention from researchers and academies there are many variables, which may have significant influence on the disclosure of non-financial information like organisational culture, identity of the firm, decision-maker characteristics (Ali et al., 2017).

The presented results have several theoretical and practical implications, as in some cases a moderate correlation has been detected. First of all the fact that only a few statistically relevant dependencies could have been determined implicates that the issue of determinants and motivations of disclosure of non-financial information needs further research as in many cases the statistically relevant influence of the chosen variables could not been replicated. This may indicate that important variables might have been missed. One explanation of it could be the mentioned country variety. However in order to verify 
it wide-ranging, cross-national studies would have to be carried out. The results also show that the chosen organisational characteristics do not determine the detail of disclosed non-financial information and therefore do not close the door of reporting for smaller organizations, operating locally, with weaker financial performance. Especially due to the relatively high number of organisation not disclosing any non-financial information and the relatively weak public pressure for corporate social responsibility reporting it is important to understand the different determinants and motives for disclosure of non-financial information. The presented results contribute to this understanding and therefore may be of interest for decision makers and policymakers in a process of strengthening the scope and improving the quality of CSR reporting.

\section{REFERENCES}

Adams, C.A. (2002). Internal organisational factors influencing corporate social and ethical reporting: Beyond current theorising. Accounting, Auditing \& Accountability Journal, 15(2), 223-250. doi:10.1108/09513570210418905.

Ali, W., Frynas, J.G. \& Mahmood, Z. (2017). Determinants of corporate social responsibility (CSR) disclosure in developed and developing countries: A literature review. Corporate Social Responsibility and Environmental Management, 24(4), 273-294. doi:10.1002/csr.1410.

Bewley, K. \& Li, Y. (2000). Disclosure of environmental information by Canadian manufacturing companies: A voluntary disclosure perspective. In: Advances in Environmental Accounting and Management (Vol. 1, pp. 201-226).

Borys, T. (2015). Zrównoważony rozwój organizacji - co chcemy lub powinniśmy równoważyć? Prace Naukowe Uniwersytetu Ekonomicznego we Wrocławiu, 376, 13-24. doi:10.15611/pn.2015.376.01.

Borys, T. \& Czaja, S. (2009). Badania nad zrównoważonym rozwojem w polskich ośrodkach naukowych. In: D. Kiełczewski (ed.), Od koncepcji ekorozwoju do ekonomii zrównoważonego rozwoju (pp. 51-75). Białystok: Wydawnictwo Wyższej Szkoły Ekonomicznej.

Bouten, L., Everaert, P., Van Liedekerke, L., De Moor, L. \& Christiaens, J. (2011). Corporate social responsibility reporting: A comprehensive picture? Accounting Forum, 35(3), 187-204. doi:10.1016/j.accfor.2011.06.007.

Brammer, S. \& Pavelin, S. (2008). Factors influencing the quality of corporate environmental disclosure. Business Strategy and the Environment, 17(2), 120-136. doi:10.1002/bse.506. 
Campbell, J.L. (2007). Why would corporations behave in socially responsible ways? An institutional theory of corporate social responsibility. Academy of Management Review, 32(3), 946-967.

Clarkson, P.M., Li, Y., Richardson, G.D. \& Vasvari, F.P. (2008). Revisiting the relation between environmental performance and environmental disclosure: An empirical analysis. Accounting Organizations and Society, 33(4-5), 303-327. doi:10.1016/j.aos.2007.05.003.

Cormier, D., Magnan, M. \& Van Velthoven, B. (2005). Environmental disclosure quality in large German companies: Economic incentives, public pressures or institutional conditions? European Accounting Review, 14(1), 3-39. doi: 10.1080/0963818042000339617.

Dienes, D., Sassen, R. \& Fischer, J. (2016). What are the drivers of sustainability reporting? A systematic review. Sustainability Accounting Management and Policy Journal, 7(2), 154-189. doi:10.1108/sampj-08-2014-0050.

European Commission (2014). Directive 2014/95/EU of the European Parliament and the Council of 22 October 2014 amending Directive 2013/34/EU as regards disclosure of non-financial and diversity information by certain large undertakings and groups. ABlEU L, 330, 1-9.

Fifka, M.S. (2013). Corporate Responsibility Reporting and its Determinants in Comparative Perspective - a Review of the Empirical Literature and a Meta-analysis. Business Strategy and the Environment, 22(1), 1-35. doi:10.1002/bse.729

Freedman, M. \& Jaggi, B. (2011). Global warming disclosures: Impact of Kyoto Protocol across countries. Journal of International Financial Management \& Accounting, 22(1), 46-90. doi:10.1111/j.1467-646X.2010.01045.x.

Gallego-Alvarez, I., Rodriguez-Dominguez, L. \& Garcia-Sanchez, I.M. (2011). Study of some explanatory factors in the opportunities arising from climate change. Journal of Cleaner Production, 19(9-10), 912-926. doi:10.1016/j. jclepro.2011.02.012.

Garcia-Sanchez, I.M., Cuadrado-Ballesteros, B. \& Frias-Aceituno, J.V. (2016). Impact of the institutional macro context on the voluntary disclosure of CSR information. Long Range Planning, 49(1), 15-35. doi:10.1016/j.lrp.2015.02.004.

Gray, R., Kouhy, R., \& Lavers, S. (1995). Corporate social and environmental reporting. A review of the literature and a longitudinal study of UK disclosure. Accounting, Auditing \& Accountability Journal, 8(2), 47-77. doi:10.1108/09513579510146996.

Hawrysz, L. (2016a). Environmental Aspects of CSR Reporting in Polish Chemistry Sector Enterprices Listed on the Warsaw Stock Exchange. Paper presented at the Ecology, Economics, Education and Legislation Conference Proceedings, Sgem 2016, Vol. III, Sofia. 
Hawrysz, L. (2016b). Social aspects of CSR reporting in Polish banks listed on the Warsaw Stock Exchange. In: Sgem 2016, Bk 2: Political Sciences, Law, Finance, Economics and Tourism Conference Proceedings (Vol. IV, pp. 587-594). Sofia: Stef92 Technology Ltd.

Hawrysz, L. (2017). Przygtowanie spółek giełdowych do ujawniania informacji pozafinansowych. Prace Naukowe Uniwersytetu Ekonomicznego we Wrocławiu, 470, 40-51. doi:10.15611/pn.2017.470.04.

Hawrysz, L. \& Maj, J. (2017). Identification of Stakeholders of Public Interest Organisations. Sustainability, 9(9), 13. doi:10.3390/su9091609.

Habek, P. (2017). CSR Reporting practices in visegrad group countries and the quality of disclosure. Sustainability, 9(12), 2322.

Jackson, G. \& Apostolakou, A. (2010). Corporate social responsibility in Western Europe: An institutional mirror or substitute? Journal of Business Ethics, 94(3), 371-394. doi:10.1007/s10551-009-0269-8.

Khanna, T., Palepu, K.G. \& Srinivasan, S. (2004). Disclosure practices of foreign companies interacting with US markets. Journal of Accounting Research, 42(2), 475-508. doi:10.1111/j.1475-679X.2004.00146.x.

Kleinfeld, A. \& Martens, A. (2014). Transparenz: Berichterstattung über Nachhaltigkeitsleistungen. In: T. Schulz \& S. Bergius (eds.), CSR und Finance: Beitrag und Rolle des CFO für eine Nachhaltige Unternehmensführung (pp. 219-235). Berlin, Heidelberg: Springer Berlin Heidelberg.

Knudsen, J.S., Moon, J. \& Slager, R. (2015). Government policies for corporate social responsibility in Europe: A comparative analysis of institutionalisation. Policy and Politics, 43(1), 81-99. doi:10.1332/030557312x656016.

Kozlowski, A., Searcy, C., \& Bardecki, M. (2015). Corporate sustainability reporting in the apparel industry: An analysis of indicators disclosed. International Journal of Productivity and Performance Management, 64(3), 377-397. doi:10.1108/ijppm-10-2014-0152.

Krasodomska, J. (2015). CSR disclosures in the banking industry: Empirical evidence from Poland. Social Responsibility Journal, 11(3), 406-423. doi:10.1108/ SRJ-02-2013-0019.

Maj, J. (2017). Diversity and corporate social responsibilty reporting in enterprises from the energy industry listed on the warsaw stock exchange. Paper presented at the International Multidisciplinary Scientific GeoConference Surveying Geology and Mining Ecology Management, SGEM.

Martinez-Ferrero, J. \& Garcia-Sanchez, I.M. (2017). Coercive, normative and mimetic isomorphism as determinants of the voluntary assurance of sustainability reports. International Business Review, 26(1), 102-118. doi:10.1016/ j.ibusrev.2016.05.009. 
Matten, D. \& Moon, J. (2008). "Implicit” and “explicit” CSR: A conceptual framework for a comparative understanding of corporate social responsibility. Academy of Management Review, 33(2), 404-424. doi:10.5465/amr.2008.31193458.

Moura-Leite, R.C. \& Padgett, R.C. (2011). Historical background of corporate social responsibility. Social Responsibility Journal, 7(4), 528-539. doi:10.1108/ 1747111111117511.

Nikolaeva, R. \& Bicho, M. (2011). The role of institutional and reputational factors in the voluntary adoption of corporate social responsibility reporting standards. Journal of the Academy of Marketing Science, 39(1), 136-157. doi:10.1007/ s11747-010-0214-5.

O'Donovan, G. (2002). Environmental disclosures in the annual report: Extending the applicability and predictive power of legitimacy theory. Accounting, Auditing \& Accountability Journal, 15(3), 344-371. doi:10.1108/09513570210435870.

Ortas, E., Gallego-Alvarez, I., \& Etxeberria, I.A. (2015). Financial factors influencing the quality of corporate social responsibility and environmental management disclosure: A quantile regression approach. Corporate Social Responsibility and Environmental Management, 22(6), 362-380. doi:10.1002/csr.1351.

Reverte, C. (2009). Determinants of corporate social responsibility disclosure ratings by Spanish listed firms. Journal of Business Ethics, 88(2), 351-366. doi:10.1007/s10551-008-9968-9.

Skrzypek, E. (2015). Społeczna odpowiedzialność - standardy i raportowanie. Prace Naukowe Uniwersytetu Ekonomicznego we Wroclawiu, 378, 206-217. doi:10.15611/pn.2015.378.16.

Sridhar, K. (2012). Is the Triple Bottom Line a restrictive framework for non-financial reporting? Asian Journal of Business Ethics, 1(2), 89-121. doi:10.1007/ s13520-011-0010-4.

Williamson, D. \& Lynch-Wood, G. (2008). Social and environmental reporting in UK company law and the issue of legitimacy. Corporate Governance, 8(2), 128-140. doi:10.1108/14720700810863760. 


\section{DETERMINANTY UJAWNIANIA INFORMACJI O SPOKECZNEJ ODPOWIEDZIALNOŚCI PRZEDSIĘBIORSTW PRZEZ ORGANIZACJE W POLSCE}

Tło badań. Dotychczasowe badania sugeruja, że organizacje mają skłonność do selektywnego ujawniania pozafinansowych informacji. Może to wynikać z charakteru danej organizacji, ogólnych i wewnętrznych czynników kontekstualnych. Dodatkowo wskazuje się na możliwą zależność pomiędzy raportowaniem danych pozafinansowych a krajem, w którym organizacja ma siedzibę.

Cel badań. W związku z powyższym głównym celem niniejszego opracowania jest sprawdzenie, czy wybrane zmienne: wielkość organizacji, fakt funkcjonowania na rynkach międzynarodowych oraz wyniki finansowe, wpływają na szczegółowość udostępnianych danych pozafinansowych.

Metodologia. W tym celu zrealizowano badanie CATI ze 102 przedsiębiorstwami notowanymi na Warszawskiej Giełdzie Papierów Wartościowych. Pozyskane dane zostały poddane analizie z wykorzystaniem współczynnika kontyngencji V Cramera.

Kluczowe wnioski. Przeprowadzone badania oraz analiza pokazały, że w większości analizowanych przypadków nie można wskazać statystycznie istotnych zależności. Statystycznie istotne związki zostały zdiagnozowane pomiędzy m.in. wielkościa organizacji a ujawnianiem wewnętrznym interesariuszom informacji społecznych i związanych z pracownikami, pomiędzy faktem funkcjonowania na rynkach międzynarodowych a ujawnianiem zewnętrznym interesariuszom informacji społecznych i związanych z pracownikami oraz pomiędzy wynikami finansowymi organizacji a ujawnianiem interesariuszom zewnętrznym informacji $\mathrm{w}$ trzech analizowanych obszarach.

Słowa kluczowe: społeczna odpowiedzialność przedsiębiorstw, raportowanie danych pozafinansowych, społeczna odpowiedzialność organizacji, zrównoważone raportowanie, ujawnianie danych pozafinansowych. 